\title{
The Relationship Among Entrepreneurship Tendency, Income Level and Life Satisfaction of Future Business People: Generation Z
}

\author{
Funda Kılıç ${ }^{1}$ \\ ${ }^{1}$ Independent Researcher, Istanbul, Turkey \\ Correspondence: Dr. Funda Kılıç, Independent Researcher, Istanbul, Turkey. Orcid No:0000-0001-9479-2755
}

Received: December 27, 2021

Accepted: January 27, 2022

Online Published: January 31, 2022

doi:10.5539/ibr.v15n3p1

URL: https://doi.org/10.5539/ibr.v15n3p1

\begin{abstract}
The aim of the study to examine the relation among entrepreneurship tendency, income level and life satisfaction of future business people generation $\mathrm{Z}$. The research was conducted on 215 business administration faculty students of a private university in Istanbul. Questionnaire application was used as research data collection method. The survey response rate of faculty students is $72 \%$. For life satisfaction Diener, Emmons, Larsen and Griffin (1985) developed a single sub-dimension scale was used. Life satisfaction scale consists of 5 propositions. Caird (2013)'s scale named shortly Get2Test (General measure of Enterprising Tendency test) was used with 54 items in order to measure entrepreneur tendency. As a result of the factor analysis, the entrepreneurship tendency variable was divided into three sub-dimensions: the need for achievement, creativity and risk taking. The results show that those three factors explain the \%60.65 of the total variance. For three factors' subscales Cronbach's alpha analysis show that three factors' subscales have reliabilities higher than ,70 which indicated high internal consistency. The factor analysis of life satisfaction shows that the rate of explanatory is $62,45 \%$ and Cronbach's alpha value is 0.72 . As a result of analysis, the relationship between the two variables, was tested and accepted by regression and correlation analysis. There is a positive relationship between entrepreneurship tendency and life satisfaction, in other words, as individuals' tendencies towards entrepreneurship increase, their life satisfaction also increases. There are differences based on ANOVA test analysis in the entrepreneurial tendency and need for achievement of the $\mathrm{Z}$ generation according to the income level. Individuals with lower income levels have higher entrepreneurial tendencies and needs for achievement.
\end{abstract}

Keywords: entrepreneurship tendency, life satisfaction, income level

\section{Introduction}

Today, the concept of entrepreneurship has an important place in the field of social sciences since it has been a powerful factor in the development of countries. Entrepreneurship increases social quality as a combination of innovation, creativity, capability, knowledge and capital (Shane \& Venkataraman, 2000). Entrepreneurship is a concept that includes using imagination, being creative, taking responsibility, organizing ideas, making decisions and establishing relationships with other people while doing all these (Bridge, O'Neil \& Cromie, 1998). Within the scope of business and economics literature, entrepreneurship is an important factor in reducing unemployment as a fundamental factor in sustainable economic growth and increased welfare. The scope of entrepreneurship is very wide. Entrepreneurship, which is a common work area, is accepted as important for all world societies.

Countries can diversify their economies to the extent that they can shape this power, the share of higher technologies in their production with new products and innovative processes. According to Adigüzel, Batur and Ekşili (2014) generation refers to born in similar temporal periods, consisting of economic and social movements or belonging to a particular social environment. In this context, each generation has different qualities, criteria for evaluating events and phenomena. Individuals of generation $\mathrm{Z}$ are born with advanced technologies. As they have grown up in technological environment, they have a technology-oriented lifestyle. Since the individuals of generation $\mathrm{Z}$ live in a world where competition is intense, however while previous generations stepped into working life at a young age, most of this generation individuals do not desire to work at early age (Bekman, 2021). The necessity of working experience of generation $\mathrm{Z}$ is at a later age compared to other generations.

The aim of the research is to examine the relationship between entrepreneurial tendency and life satisfaction and to determine the effect of income level on entrepreneurial tendency of future business people generation $\mathrm{Z}$. 
Although there are many studies in the literature based on the personality types, well being, happiness with entrepreneurship tendency (Dockery, 2004; Örücü, Kılıç \& Özer, 2007; Yılmaz \& Günel; 2011) studies on life satisfaction and entrepreneurship tendencies are very limited, and this research will fill an important gap in the literature. In the literature part of the study, entrepreneurshp tendency and sub-dimensions, life satisfaction variables, those relations based on generation $\mathrm{Z}$ are defined. In methodology part, research sample, measurements and findings related to study is explained. In conclusion part, the analyzes based on the findings are discussed in terms of entrepreneurship literature. Research limitations and suggestions for future studies are included in this section.

\section{Literature Review}

\subsection{Entrepreneurship Tendency and Generation $Z$}

Entrepreneurship features include creativity, diligence, not being afraid of difficulties, tolerance to uncertainty (Ferrante, 2005; Karabulut, 2015), need for achievement, locus of control, tendency to take risks (Bakan, Eyitmiş, Büyükbeşe, Erşahan 2012; Bygrave, 1989), self-confidence. (Robinson, Stimpson, Huefner \& Hunt, 1991), innovation (Bozkurt \& Erdurur, 2013; Koh, 1996), the ability to seize and retain profitable opportunities (Littunen, 2000), to see changes as new and important opportunities, to attach importance to details and to try to realize the best (Lambing \& Kuehl, 2000) can be displayed. Schumpeter (1993) introduced the concept of innovation to entrepreneurship and defined five situations for entrepreneurs: creating a new product or a different quality of an existing product, introducing a new production method, creating a new market, finding new sources of raw materials or obtaining semi-finished products, succeed in establishing a new organization in an industry setting. Drucker (1998) emphasized the concept of entrepreneurship to change as an opportunity and use it to gain competitive advantage. Shapero \& Sokol (1982) argued that social variables and socio-cultural environment components affect entrepreneurship. According to their study, entrepreneurship consists of taking initiative, combining resources, management, autonomy and risk taking tendencies. In the study of Ulama (2016), the entrepreneurial tendency is defined as "the person's tendency to make an attempt", it is the tendency of individuals to enter entrepreneurship before they engage in entrepreneurial activity. Entrepreneurial individuals have the knowledge and characteristics necessary to undertake an enterprise. seize the opportunities that come their way. Entrepreneurial characteristics of individuals their desires and desires to become an entrepreneur, to establish their own business, closely related to entrepreneurial trends.

According to Caird (2013)'s approach entrepreneur tendecy has five dimensions: risk taking, creative tendency, need for achievement, need for autonomy and internal locus of control. Donovan \& Jessor (1985) define risk taking as a form of social deviation. Levenson \& Gottman (1985) defines risk taking as all purposeful activities that cause novelty or danger, causing anxiety in most people. Creative tendency; people who desire to come up with new ideas, solve problems in new approach, are curious to learn (Caird, 2013). The need for achievement theory put forward by McClelland (1961) and argues that the need for success is a factor that affects entrepreneurial behavior. In this context, people with a high need for achievement motivation are more willing to succeed. This causes their entrepreneurship tendencies to be higher. Need for autonomy; basically want to have control of their own hands, they want to express their creativity in business environments (Cromie, 2000). Internal locus of control is based on social learning theory. Individuals showing an internal locus of control tend to take advantage of opportunities, believe in themselves, and feel in charge to achieve success (Caird, 2013).

Generation refers to born in similar temporal periods, consisting of economic and social movements or belonging to a particular social environment (Adıgüzel et al, 2014). In order to determine the differences among generations is not easy, in other words it is seen that it is not easy to underline the difference (Kırık \& Köyüstü, 2018). According to Yüksekbilgili (2013) fundamentals that may affect business generations are generally divided into four groups. These are in order: traditional, baby boomers are generation $\mathrm{X}$ and generation $\mathrm{Y}$. But especially in recent years, as a new generation named Generation $\mathrm{Z}$ is also on the agenda. Generation $\mathrm{Z}$ is refered to people who born in the 1990's and raised in the 2000s (Levickaite, 2010). This period is affected by technological developments such as web, internet, smart phones, laptops, freely available networks and digital media (Nagy \& Székely 2016). Generations Z is grown up with the digital environment (Prensky, 2001) and they are more likely to be entrepreneurial and tolerant than Generaiton Y. In addition they are more realistic in their life style and optimistic about the future. Tari (2011) describes Generation $\mathrm{Z}$ that they are sensitive to environmental issues such as climate change and sustainability. In addition they tend to work in business environment giving opportunities for learning and development and encourage their entrepreneurial skills. Technology is very dominant in their lives and prefers organizations that are flexible. They prefer to work for a leader with honesty and integrity. In 2000 and later, technology has advanced all over the World. Generation Z formed in this period is different from other generations. The main feature that distinguishes them is that they are 
very ambitious and also has materialistic ideas. Another difference of the $\mathrm{Z}$ generation from other generations is that they share information very quickly and to be able to receive, analyze and comment on the subject in a way that (Mishra, Sarkar \& Singh, 2012).

\subsection{Entrepreneurship Tendency and Life Satisfaction}

Life satisfaction can be defined as a positive evaluation of the whole of life, not related to a specific field, and therefore, just being satisfied with one's job does not mean that he is satisfied with his life (Haybron, 2004). Job satisfaction can increase life satisfaction but does not replace it. The object of life satisfaction is all areas of life (Veenhoven, 1996b). The fact that the individual's positive evaluations of his life are higher than negative evaluations indicate that the quality of life is also higher (Myers \& Diener, 1995). Life satisfaction is a subjective concept that varies from person to person therefore it is very difficult to define. In the study of Yetim (2003), individualist and collectivist states that the level of satisfaction from life differs according to cultures. Individualistic societies they are closely concerned with their own happiness. A study by Y1lmaz \& Altınok (2009), the life satisfaction of school principals with a high income level and a low income level higher than those expectations from life. Another study revealed a significant relationship between education level and life satisfaction, life satisfaction of employees who have a university degree compared to other employees was higher (Yenihan, Öner \& Balc1, 2016). Life satisfaction of individuals can be affected by many factors. Some of these are daily happiness from life, meaning attributed to life, harmony in reaching goals, positive individual identity, physical well-being, economic, security and are social relations (Myers \& Diener, 1995).

According to the research conducted by Y1lmaz \& Günel (2011) entrepreneurs have started their entrepreneurial activities due to social drastic factors such as unemployment, family tradition, need for independence, or lack of personal or financial security. Örücü, K1lıç \& Yılmaz's study (2007) shows that entrepreneurial tendencies of individuals are affected by family income while whether there is an entrepreneur in the family had no effect on entrepreneurial tendency. In addition, male students tend to be more entrepreneurial than female students. İbicioğlu, Özdaşlı \& Alparslan (2009) examined the effect of family on entrepreneurship tendency, the age of the parents, gender and education level found to be effective in their children' choice. Eleren \& Sadykova's study (2016) showed that there is a positive and significant relationship between happiness and innovation, need for independence, creativity but they also found that there is a negative relationship between happiness and risk-taking. In the light of these explanations;

H1: There is a positive relationship between entrepreneurship tendency and life satisfaction.

When the literature on life satisfaction is examined, examples of the basic factors affecting the concept are freedom, democracy, being open-minded, being active, political stability, feeling in control of one's own life, being physically and mentally sound, being married, being in good relations with family and friends (Dockery, 2004; Özdevecioğlu \& Aktas, 2007) can be given. Örücü at al (2007) obtained the following results in the study titled "The Effect of Familial Factors on Entrepreneurial Tendency of University Students": While it is seen that entrepreneurial tendencies of individuals are affected by family income; It has been concluded that upbringing and being an entrepreneur in the family have no effect on the entrepreneurial tendency of senior university students. In addition, it has been determined that male students tend to be more entrepreneurial than female students.

$\mathrm{H} 2$ : There is a significant difference among income levels on the entrepreneurship tendency.

Life satisfaction is important for university students as well as for all age groups. Most of the students who will start university are different from their hometowns have the difficulties of adapting new situations, academic challenges and social networks, they are also faced with situations such as the need (Matheny, Curlette, Aysan, Herrington, Gfroerer, Thompson, \& Hamarat, 2002). This situation requires students to get used to a new life and many causes significant changes in the life of the young person and mental problems (Özgür, Babacan \& Durdu, 2010).

H3: There is a significant difference among income levels on the need for achievement. 


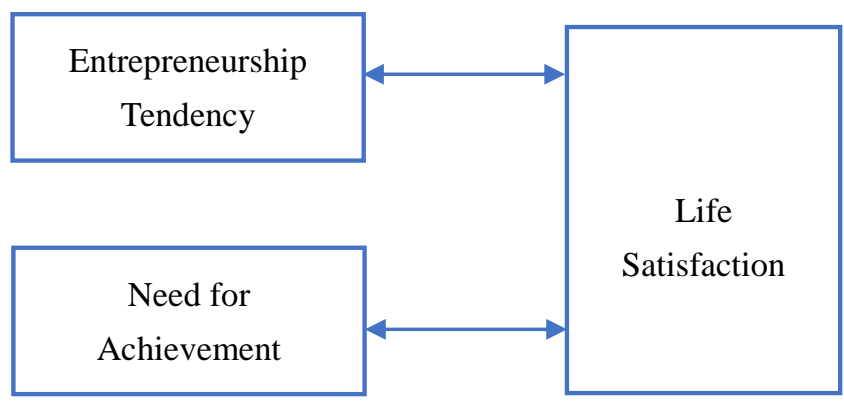

Figure 1. Research Model I

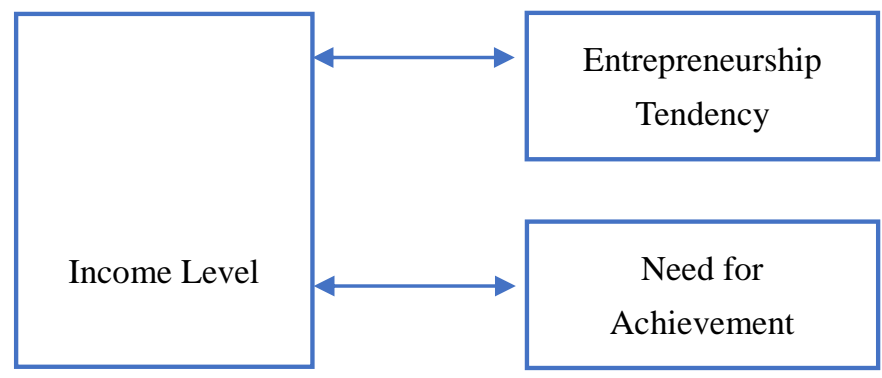

Figure 2. Research Model II

\section{Method}

\subsection{Participant Characteristics and Sample Size}

The research was conducted on 215 business administration faculty students of a private university in Istanbul. Universities in Turkey are divided into two types as state and foundation universities. State universities are the universities where students have education without paying any fee, while foundation universities are the universities where students pay a certain annual fee. Therefore, it can be assumed that the socio-economic levels of the students who prefer a private university without a scholarship are good, but it cannot be generalized. Because students who score high in the university entrance exam in Turkey can also choose private universities by gaining the right to a scholarship.

\subsection{Sampling Procedures}

Questionnaire application was used as research data collection method. The survey response rate of faculty students is $72 \%$ (215/300). A total of 300 questionnaires were sent to the students of the department of business administration, 215 of which were filled. According to the demographic data obtained for 215 people as a result of the questionnaire applied in the research, $45 \%$ of the sample consists of female students and $55 \%$ of male students. As seen in Table 1, 39\% of the students are between the ages of 18-20,35\% are between the ages of $21-23$, and $26 \%$ are between the ages of 24-25. In their monthly budgets, it is seen that approximately $45 \%$ of them are 1,000 TL or less. $47 \%$ of the sample is in the prep and first year grade in university. 
Table 1. Descriptives Statistics

\begin{tabular}{llrcc}
\hline $\mathrm{N}=215$ & & Frequency & $\%$ & Cumulative \% \\
\hline Gender & Female & 97 & 45 & 45 \\
Age & Male & 118 & 55 & 100 \\
& & & & \\
& $18-20$ & 84 & 39 & 64 \\
Monthly Budget & $21-23$ & 75 & 35 & 74 \\
& $24-25$ & 56 & 26 & 100 \\
& & & & \\
& 0-1000 TL & 96 & 44,5 & 44,5 \\
& 1001-2000 TL & 67 & 31,3 & 75,8 \\
& 2001-3000 TL & 27 & 12,5 & 88,3 \\
& 3001-4000 TL & 14 & 6,3 & 94,6 \\
Class & 4001-+ & 6 & 2,7 & 97,3 \\
& 5001 TL - + & 6 & 2,7 & 100 \\
& & & & \\
& Prep & 26 & 12 & 1,1 \\
& 1. Grade & 75 & 35 & 36,1 \\
& 2. Grade & 54 & 25 & 61,1 \\
& 3. Grade & 43 & 20 & 81,1 \\
& 4. Grade & 41 & 19 & 100 \\
\hline
\end{tabular}

\subsection{Instruments}

For life satisfaction, Diener, Emmons, Larsen and Griffin (1985) developed a single sub-dimension scale was used. Life satisfaction scale consists of 5 propositions. Propositions such as "I got the important things I wanted in life so far", "I am satisfied with my life", "I have a life close to my ideals", "My living conditions are perfect", "If I were born again, I wouldn't change almost anything in my life" are among the propositions expressed on the life satisfaction scale. Caird's (2013) scale named shortly Get2Test (General measure of Enterprising Tendency test) was used with 54 items in order to measure entrepreneurship tendency. It has five dimensions: risk taking, creative tendency, need for achievement, need for autonomy and internal locus of control. Propositions such as "I would not mind routine unchallenging work if the pay and pension prospects were good", "I like to test boundaries and get into areas where few have worked before", "I find it difficult to switch off from work completely", "Sometimes people find my ideas unusual", "I would prefer to have a moderate income in a secure job rather than a high income in a job that depended on my performance", "Many of the bad times that people experience are due to bad luck", If I wanted to achieve something and the chances of success were 50/50", "I would take the risk", "I try to accept that things happen to me in life for a reason", "You are not likely to be successful unless you are in the right place at the right time", "For me, getting what I want is a just reward for my efforts" are among the propositions.

\section{Results}

As a result of the factor analysis, the entrepreneurship tendency variable was divided into three sub-dimensions: the need for achievement, creativity and risk taking. The KMO (Kaiser-Meyer-Olkin) measure of sampling adequacy was larger than ,50, and Barlett test value was significant for this analysis, showing that it statistically appropriate to rely on the results of the factor analysis. The results show that those three factors explain the $\% 60.65$ of the total variance as in Table 2. For three factors' subscales Cronbach's alpha coefficients were found in order to test internal reliabilities. The analysis show that three factors' subscales have reliabilities higher than ,70 which indicated high internal consistency.

Table 2. Factor Analysis of Entrepreneurship Tendency 


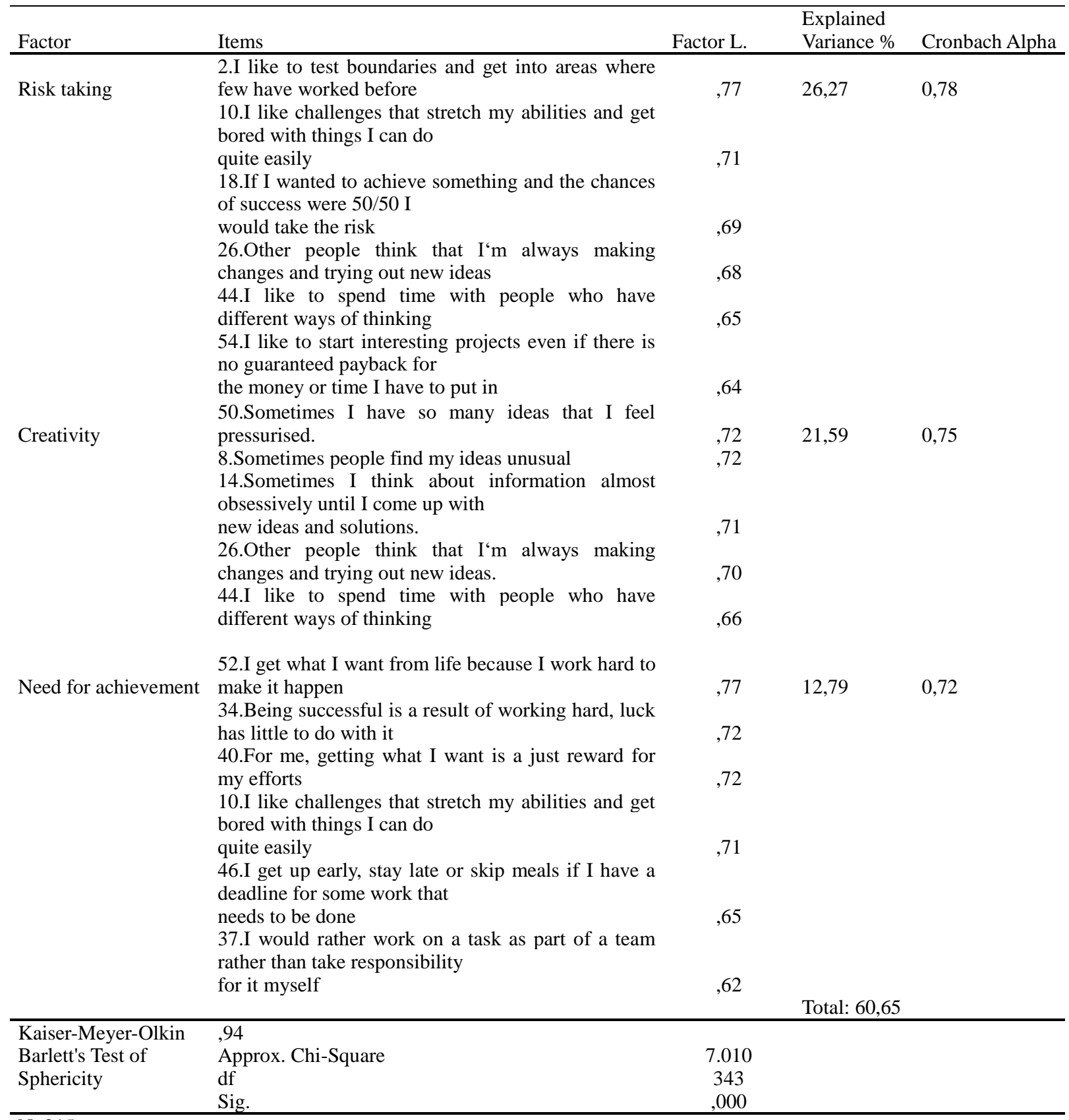

$\mathrm{N}: 215$

The factor analysis of life satisfaction shows that the rate of explanatory is $62,45 \%$ and conbach's alpha value is 0.72 and factor explains the $\% 62.45$ of the total variance as in Table 3. For life satisfaction factor subscales Cronbach's alpha coefficients were found in order to test internal reliabilities.

Table 3. Factor Analysis of Life Satisfaction

\begin{tabular}{llll}
\hline Factor Items & Factor & Explained & Cronbach \\
\hline
\end{tabular}




\begin{tabular}{|c|c|c|c|c|}
\hline \multirow{2}{*}{ Life Satisfaction } & & $\mathrm{L}$. & Variance $\%$ & Alpha \\
\hline & $\begin{array}{l}\text { 55.I have a life close to my ideals } \\
\text { 56.My living conditions are perfect } \\
\text { 57.I am satisfied with my life } \\
\text { 58.I got the important things I wanted in life so far } \\
\text { 59.If I were born again, I wouldn't change almost anything in my life }\end{array}$ & $\begin{array}{l}76 \\
, 72 \\
70 \\
, 67 \\
, 65\end{array}$ & 54,21 & ,72 \\
\hline & & & Total: 62,45 & \\
\hline $\begin{array}{l}\text { KMO } \\
\text { Barlett's Test of } \\
\text { Sphericity }\end{array}$ & $\begin{array}{l}0,78 \\
\text { Approx. Chi-Square } \\
\text { df } \\
\text { Sig. }\end{array}$ & $\begin{array}{c}3.747 \\
55 \\
, 000\end{array}$ & & \\
\hline
\end{tabular}

$\mathrm{N}: 215$

According to correlation analysis, there is positive relation between entrepreneurship tendency and life satisfaction which was approved H1 in Table 4. When we figured out the sub-dimensions of entrepreneurship tendency it is obviously seen that there is positive relation between life satisfaction and risk taking and need for achievement. According to result of regression analyses entrepreneurship tendency significantly affect life satisfaction. The analysis indicated that entrepreneurship tendency was accounted for $18 \%$ of the amount of the variation in the dependent variable of life satisfaction as in Table 6.

Table 4. Correlation Analysis

\begin{tabular}{lccc}
\hline Variables & Mean & SD & Entrepreneurship Tendency \\
\hline Entrepreneurship Tendency & 3,34 & 0,61 & 1 \\
Life Satisfaction & 3,21 & 0,59 &, $54^{* *}$ \\
N: 215 & & & \\
$* *$ Correlation is significant at the 0.01 level (2-tailed) \\
\hline
\end{tabular}

Table 5. Correlation Analysis of the Variables of Sub-dimensions

\begin{tabular}{|c|c|c|c|c|c|c|c|}
\hline Variables & Mean & SD & $\begin{array}{l}\text { Risk } \\
\text { Taking }\end{array}$ & Creativity & $\begin{array}{l}\text { Need for } \\
\text { Achievement }\end{array}$ & $\begin{array}{l}\text { Entrepreneurship } \\
\text { Tendency }\end{array}$ & $\begin{array}{l}\text { Life } \\
\text { Satisfaction }\end{array}$ \\
\hline Risk Taking & 3,51 & 0,59 & 1 & & & & \\
\hline Creativity & 3,45 & 0,72 & $44 * *$ & 1 & & & \\
\hline Need for Achievement & 3,37 & 0,74 &, $28 * *$ & & 1 & & \\
\hline Entrepreneurship Tendency & 3,34 & 0,48 & $66 * *$ &, $65 * *$ &, $66 * *$ & 1 & \\
\hline Life Satisfaction & 3,21 & 0,74 &, $17 * *$ & - &, $22 * *$ &, $54 * *$ & 1 \\
\hline \multirow{2}{*}{\multicolumn{8}{|c|}{$\begin{array}{l}\text { N: } 215 \\
* * \text { Correlation is cionificant at the } 001 \text { level }(2-t a i l e d\end{array}$}} \\
\hline & & & & & & & \\
\hline
\end{tabular}

Table 6. Regression Analysis

\begin{tabular}{llll}
\hline Dependent Variable & \multicolumn{3}{l}{ Life Satisfaction } \\
Independent Variables & \multicolumn{4}{l}{ Entrepreneurship Tendency } \\
Adjested R2:, 18 & F Test: 16,839 & Significance:, 00 \\
Variables in equation & Beta & T & p \\
Entrepreneurship Tendency & 0,316 & 4,1 & 0 \\
\hline
\end{tabular}

One-way ANOVA test was conducted whether there were any differences in terms of monthly budget. At the first step, homogeneity of the groups was tested with Levene test. According to Levene test result we accepted the groups are not equal $(\mathrm{P}=0,65>0,05)$ and ANOVA may be conducted. For understanding which groups of the participants show difference, Sheffe and Tukey's tests were accomplished. Because of groups are not equal, Sheffe test results were preferred. According to Sheffe test results it was found that there is a difference on their income level. For understanding the amount of this difference, Descriptive Table was checked. According to Table 7. mean of the 0-1.000 TL was 3,5199, mean of the 1001-2000 TL was 3,4657. It can be said that need for achievement $(3,5199)$ and entrepreneurship tendency $(3,503)$ in Table 8 . level based on lowest monthly budget is at the highest level when compared with the other levels. 
Table 7. ANOVA Test of Need for Achievement and Income Level

\begin{tabular}{|c|c|c|c|c|c|}
\hline & & $\mathrm{N}$ & Mean & $\mathrm{F}$ test & $\mathrm{p}$ \\
\hline \multirow{6}{*}{ Need for Achievement } & $0-1000 \mathrm{TL}$ & 96 & 3,5199 & 5,177 &, 000 \\
\hline & $1001-2000 \mathrm{TL}$ & 67 & 3,4657 & & \\
\hline & 2001-3000 TL & 27 & 3,3535 & & \\
\hline & $3001-4000 \mathrm{TL}$ & 14 & 3,1325 & & \\
\hline & 4001 TL ve + & 12 & 3,3134 & & \\
\hline & & & Mean Difference & Std. Error & $\mathrm{p}$ \\
\hline \multirow[t]{20}{*}{ Scheffe Test } & $0-1000 \mathrm{TL}$ & $1001-2000 \mathrm{TL}$ & $-0,048$ & 0,049 &, 002 \\
\hline & & 2001-3000 TL & $-0,017$ & 0,068 & 000 \\
\hline & & $3001-4000 \mathrm{TL}$ &, $33929^{*}$ & 0,090 &, 000 \\
\hline & & 4001 TL ve üzeri & 0,158 & 0,096 & 000 \\
\hline & $1001-2000 \mathrm{TL}$ & $0-1000 \mathrm{TL}$ & 0,048 & 0,049 &, 002 \\
\hline & & $2001-3000 \mathrm{TL}$ & 0,031 & 0,071 & 000 \\
\hline & & $3001-4000 \mathrm{TL}$ & ,38738* & 0,092 & 000 \\
\hline & & 4001 TL ve üzeri & 0,206 & 0,098 &, 000 \\
\hline & 2001-3000 TL & $0-1000 \mathrm{TL}$ & 0,017 & 0,068 &, 000 \\
\hline & & $1001-2000 \mathrm{TL}$ & $-0,031$ & 0,071 & 000 \\
\hline & & $3001-4000 \mathrm{TL}$ & ,35670* & 0,103 & (000 \\
\hline & & 4001 TL ve üzeri & 0,176 & 0,109 & 000 \\
\hline & $3001-4000 \mathrm{TL}$ & $0-1000 \mathrm{TL}$ &,$- 33929^{*}$ & 0,090 &, 000 \\
\hline & & $1001-2000 \mathrm{TL}$ &,$- 38738^{*}$ & 0,092 & 000 \\
\hline & & $2001-3000 \mathrm{TL}$ &,$- 35670^{*}$ & 0,103 & 000 \\
\hline & & 4001 TL ve üzeri & $-0,181$ & 0,124 &, 000 \\
\hline & $4001 \mathrm{TL}-+$ & $0-1000 \mathrm{TL}$ & $-0,158$ & 0,096 &, 000 \\
\hline & & $1001-2000 \mathrm{TL}$ & $-0,206$ & 0,098 & ,000 \\
\hline & & $2001-3000 \mathrm{TL}$ & $-0,176$ & 0,109 &, 000 \\
\hline & & $3001-4000 \mathrm{TL}$ & 0,181 & 0,124 &, 000 \\
\hline
\end{tabular}

Table 8. ANOVA Test of Entrepreneurship Tendency and Income Level

\begin{tabular}{|c|c|c|c|c|c|}
\hline Entrepreneurship Tendency & $\begin{array}{l}0-1000 \mathrm{TL} \\
1001-2000 \mathrm{TL} \\
2001-3000 \mathrm{TL} \\
3001-4000 \mathrm{TL} \\
4001 \mathrm{TL} \mathrm{ve}+ \\
\end{array}$ & $\begin{array}{l}\mathrm{N} \\
96 \\
67 \\
27 \\
14 \\
12 \\
\end{array}$ & $\begin{array}{l}\text { Mean } \\
3,503 \\
3,493 \\
3,498 \\
3,292 \\
3,500 \\
\end{array}$ & $\begin{array}{l}\mathrm{F} \text { test } \\
3,437\end{array}$ & $\begin{array}{l}\mathrm{p} \\
, 000\end{array}$ \\
\hline Scheffe Test & $\begin{array}{l}0-1000 \mathrm{TL} \\
1001-2000 \mathrm{TL} \\
2001-3000 \mathrm{TL} \\
3001-4000 \mathrm{TL} \\
4001 \mathrm{TL}-+\end{array}$ & $\begin{array}{l}\text { 1001-2000 TL } \\
2001-3000 \text { TL } \\
\text { 3001-4000 TL } \\
4001 \text { TL ve üzeri } \\
0-1000 \text { TL } \\
2001-3000 \text { TL } \\
3001-4000 \text { TL } \\
4001 \text { TL ve üzeri } \\
0-1000 \text { TL } \\
1001-2000 \text { TL } \\
3001-4000 \text { TL } \\
4001 \text { TL ve üzeri } \\
0-1000 \text { TL } \\
1001-2000 \text { TL } \\
2001-3000 \text { TL } \\
4001 \text { TL ve üzeri } \\
0-1000 \text { TL } \\
1001-2000 \text { TL } \\
2001-3000 \text { TL } \\
3001-4000 \text { TL }\end{array}$ & $\begin{array}{l}\text { Mean Difference } \\
0,010 \\
0,005 \\
, 21119^{*} \\
0,003 \\
-0,010 \\
-0,005 \\
, 20114^{*} \\
-0,007 \\
-0,005 \\
0,005 \\
, 20633^{*} \\
-0,002 \\
-, 21119^{*} \\
-, 20114^{*} \\
-, 20633^{*} \\
-0,208 \\
-0,003 \\
0,007 \\
0,002 \\
0,208\end{array}$ & $\begin{array}{l}\text { Std. Error } \\
0,032 \\
0,044 \\
0,058 \\
0,062 \\
0,032 \\
0,046 \\
0,059 \\
0,063 \\
0,044 \\
0,046 \\
0,067 \\
0,070 \\
0,058 \\
0,059 \\
0,067 \\
0,080 \\
0,062 \\
0,063 \\
0,070 \\
0,080\end{array}$ & $\begin{array}{l}\mathrm{p} \\
, 000 \\
, 000 \\
, 000 \\
, 000 \\
, 002 \\
, 000 \\
, 000 \\
, 000 \\
, 000 \\
, 000 \\
, 000 \\
, 000 \\
, 000 \\
, 000 \\
, 000 \\
, 000 \\
, 000 \\
, 000 \\
, 000 \\
, 000\end{array}$ \\
\hline
\end{tabular}

Table 9. Results for Hypothesis

\begin{tabular}{lc}
\hline H1: There is a positive relationship between entrepreneurship tendency and life satisfaction & Accepted \\
H2: There is a significant difference among income levels on the entrepreneurial tendency & Accepted
\end{tabular}


H3: There is a significant difference among income levels on the entrepreneurial tendency. Accepted

$* \mathrm{P}$ is significant at the 0.01 level (2-tailed)

\section{Conclusion}

The aim of the research is to examine the relationship between entrepreneurial tendency and life satisfaction and to determine the effect of income level on entrepreneurial tendency of future business people generation $\mathrm{Z}$. Therefore this study was conducted in business administration students in university so as to understand those variables relations. While entrepreneurship literature has divided entreprenesurhip tendency five sub-dimensions; risk taking, creative tendency, need for achievement, need for autonomy and internal locus of control (Caird, 2013), in this study this variable has divided three sub-dimensions; risk taking, creativity and need for achivement. Need for autonomy and internal locus of control were eliminated due to their insufficient level of factor explanation. The relationship between the two variables, which was our first hypothesis, was tested and accepted by regression and correlation analysis. There is a positive relationship between entrepreneurship and life satisfaction, in other words, as individuals' tendencies towards entrepreneurship increase, their life satisfaction also increases. Generation $\mathrm{Z}$ has easy access to information, can deal with many different jobs at the same time, and it can be stated that there is a generation that can use communication tools effectively. This generation can access the opportunities quickly and use them effectively (Sarıbaş, Kömürcü, \& Güler, 2016). Generation $\mathrm{Z}$ is at the very center of the internet. They are more likely to expert in using technology than other generations. But especially their daily work can perform many tasks simultaneously in an easy way (Golovinski, 2011). This makes Generation $Z$ different from other generations takes a step forward. On the other hand, according to BNP Paribas research (https://group.bnpparibas/en/news/banking-generation) which was conducted in 3200 students aged 15-20, when talking about companies and working life, the French teenager says "very difficult", "very complicated" and it was observed that they used the words "boring", "brutal". A place where everything is rapidly getting old and renewed since they grew up in the world, they think that knowledge will get old quickly, they should constantly update their knowledge and themselves and are not attracted to the idea of working for the same company for years.

Our second and third hypotheses in our research are that the entrepreneurial tendency and nned for achievement of the $\mathrm{Z}$ generation will change on the basis of income level, and our analyzes have confirmed these hypotheses. There are differences in the entrepreneurial tendency and need for achievement of the $Z$ generation according to the income level. Individuals with lower income levels have higher entrepreneurial tendencies and needs for achievement. In a study conducted by Çetin \& Karalar (2016), the work life of X, Y and Z generation individuals thoughts and personal characteristics were compared and differences were determined; Generation $\mathrm{Z}$ has emerged as more realistic, creative and collaborative than other generations. The first expectations of the $\mathrm{Z}$ generation from business life are the opportunity for advancement and wages Schawbel (2014) is one of the important studies in this field, according to his research, the three things that will motivate the $\mathrm{Z}$ generation most in business life; progress opportunities, earning more money and meaningful work. In the other research, Tolstykh, Gamidullaeva, Shmeleva, Woźniak \& Wozniak (2016) stated that the Z generation individuals from the business life their expectations; effective work-life balance, pay and benefits, advancement opportunities, and institution listed as being able to have a say in business preference. In the same study, the factors that motivate the $\mathrm{Z}$ generation are determined as career opportunities and wages, mutual aid, respect and motivating work environment are among the sub-factors. With job diversity, monetary rewards, a sense of contributing to meaningful work motivation that determines job satisfaction of Generation Z (Kirchmayer \& Fratričová, 2020). In the research conducted by Pehlivan, Kılıçsal \& Kızıldağ (2019), when the questions that Generation $Z$ want to get information about in the job interview are asked, the wage is in the first place, while the promotion and career opportunities are in the second place. Besides all, whether the business will provide opportunities for them to develop themselves, they want to know whether they have working conditions based on freedom (Behrens, Muller, Whittington, Mark, Baram, Stachenfeld \& Kurth-Nelson, 2018) is another crucial issue for Generation Z. Therefore our results are consistent with literature that shows income level differs in terms of tendency to be entrepreneur and need for achievement. Our research results show that as the income level decreases, the tendency of individuals to entrepreneurship increases and similarly, their need for success increases.

Today, the changes that occur in every field are social, legal, cultural, educational and technology affects our lives. These developments also affect the social structure, by influencing the expectations, beliefs and value judgments of the people who make up the society cause changes. Generational differences today is felt more than ever. Therefore, it is getting harder and harder to create the conditions according to these differences in the business environment. Generation Z, like other generations, not only builds their careers in corporate companies, 
but also reveals their entrepreneurial preference to a great extent. On the other hand, for the $\mathrm{Z}$ generation, the variables of happiness, feeling good, satisfaction with life are important compared to other generations. This research will help to understand the $\mathrm{Z}$ generation, who is seen as the business people of the future, through the variables of entrepreneurship tendency and life satisfaction.

The research has certain limitations due to pandemic conditions. Stronger results can be obtained if the survey application, which is used as a data collection method in the research, is supported by the qualitative research method in future studies. Another limitation is that the sample is at a single university and the university is a private university. In future studies, it is recommended to diversify the sample with different departments of different universities. Universities in Turkey are divided into private and state, and although they are subject to the same regulations, the student profile they receive varies according to the university admissions conditions. This is an critical issue for studies that will examine variables based in income level of students for future studies.

\section{References}

Adıgüzel, O., Batur, H. Z., \& Ekşili, N. (2014). Kuşakların değişen yüzü ve Y kuşağı ile ortaya çıkan yeni çalışma tarzı: mobil yakalılar. Süleyman Demirel Üniversitesi Sosyal Bilimler Enstitüsü Dergisi 19, 165-182.

Bakan, İ., Eyitmiş, A. M., Büyükbeşe, T., \& Erşahan, B. (2012). Kahramanmaraş’ta girişimcilik ve yenilikçilik: profesyonel meslek gruplarında bir alan çalışması. II. Bölgesel Sorunlar ve Türkiye Sempozyuти, 260-267.

Behrens, T. E., Muller, T. H., Whittington, J. C., Mark, S., Baram, A. B., Stachenfeld, K. L., \& Kurth-Nelson, Z. (2018). What is a cognitive map? Organizing knowledge for flexible behavior. Neuron, 100(2), 490-509. https://doi.org/10.1016/j.neuron.2018.10.002

Bekman, Ö. G. (2021). Yöneticilerin Z kuşağından beklentileri, Z kuşağının iş yaşamı beklentileri. Maltepe Üniversitesi İşletme Anabilim Dalı Yüksek Lisans Tezi, Maltepe Üniversitesi Lisansüstü Eğitim Enstitüsü.

Bozkurt, Ö., \& Erdurur, K. (2013). Girişimci kişilik özelliklerinin girişimcilik eğilimindeki etkisi: potansiyel girişimciler üzerinde bir araştırma. Girişimcilik ve Kalkınma Dergisi, 8(2), 57-78.

Bridge, S., O’Neill, K., \& Cromie, S. (1998) Understanding Enterprise, Entrepreneurship and small Business. London: Macmillan Business. https://doi.org/10.1007/978-1-349-26171-0

Bygrave, W. D. (1989). The entrepreneurship paradigm (I): a philosophical look at its research methodologies. Entrepreneurship Theory and Practice, 14, 7-26. https://doi.org/10.1177/104225878901400102

Caird, S. (2013). General measure of Enterprising Tendency test.

Çetin, C., \& Karalar, S. (2016). X, Y ve Z kuşağı öğrencilerin çok yönlü ve sınırsız kariyer algıları üzerine bir araştırma. Yönetim Bilimleri Dergisi, 14(28), 157-197.

Cromie, S. (2000). Assessing entrepreneurial inclinations: Some approaches and empirical evidence. European Journal of Work and Organizational Psychology, 9(1), 7-30. https://doi.org/10.1080/135943200398030

Diener, E. D., Emmons, R. A., Larsen, R. J., \& Griffin, S. (1985). The satisfaction with life scale. Journal of personality assessment, 49(1), 71-75. https://doi.org/10.1207/s15327752jpa4901_13

Dockery, A. (2004). Happiness, Life Satisfaction and The Role of Work: Evidence from Two Australian Surveys, Unpublished Mimeo.

Donovan, J. E., \& Jessor, R. (1985). Structure of problem behavior in adolescence and young adulthood. Journal of Consulting and Clinical Psychology, 53(6), 890-904. https://doi.org/10.1037/0022-006X.53.6.890

Drucker, P. F. (1998). The discipline of innovation. Harvard Business Review, 3-8. https://doi.org/10.1002/lt1.40619980906

Eleren A., \& Sadykova, G. (2016). Girişimcilik eğilimi ile mutluluk algısı arasındaki ilişki: üniversite öğrencileri üzerinde bir araştırma. Manas Sosyal Araştırmalar Dergisi, 5(5), 190-209.

Ferrante, F. (2005). Revealing entrepreneurial talent. Small Business Economics, 25(2), 159-174. https://doi.org/10.1007/s11187-003-6448-6

Golovinski, M. (2011). Event 3.0: how generation $Y \& Z$ are re-shaping the events industry, London: Newtonstrand, 48-49.

Haybron, D. M. (2004). Happiness and the importance of life satisfaction. delivered at the Department of Philosophy, University of Arizona. 
İbicioğlu H., Özdaşlı K., \& Alparslan A. M. (2009). Girişimci özellikler ve girişimcilik türü tercihi üzerinde ebeveyn etkisi: Mehmet Akif Ersoy Üniversitesi Araştırması. Selçuk Üniversitesi Sosyal Bilimler Meslek Yüksek Okulu Dergisi, 12(1-2), 521-538.

Karabulut, T. (2015). Üniversite Öğrencilerinin Girişimcilik Özelliklerini ve Eğilimlerini Belirlemeye Yönelik Bir Araştırma. Marmara Üniversitesi İktisadi ve İdari Bilimler Dergisi, 26(1), 331-356. https://doi.org/10.20979/ueyd.40000

Kirchmayer, Z., \& Fratričová, J. (2020). What motivates generation $\mathrm{Z}$ at work? Insights into motivation drivers of business students in Slovakia. Proceedings of the Innovation management and education excellence through vision, 6019-6030.

Kırık, A. M., \& Köyüstü, S. (2018). Z kuşağı konusunda yapılmış tezlerin içerik analizi yöntemiyle inclenmesi. Gümüşhane Üniversitesi Illetişim Fakültesi Elektronik Dergisi, 6(2), 1497-1518. https://doi.org/10.19145/e-gifder.443304

Koh, C. H. (1996). Testing hypotheses of entrepreneurial characteristics: a study of Hong Kong MBA Students. Journal of Managerial Psychology, 11(3), 12-25. https://doi.org/10.1108/02683949610113566

Lambing, P., \& Kuchl, R. C. (2000). Entrepreneurship (2nd ed.). Prentince Hall.

Levenson, R. W., \& Gottman, J. M. (1985). Physiological and affective predictors of change in relationship satisfaction. Journal of Personality and Social Psychology, 49(1), 85-94. https://doi.org/10.1037/0022-3514.49.1.85

Levickaite, R. (2010) Generations X Y Z: how social networks form the concept of the world without borders the case. If Lithuania, LIMES.

Littunen, H. (2000). Entrepreneurship and the characteristics of the entrepreneurial personality. International Journal of Entrepreneurial Behavior \& Research, 6(6), 295-299. https://doi.org/10.1108/13552550010362741

Matheny, K. B., Curlette, W. L., Aysan, F., Herrington, A., Gfroerer, C. A., Thompson, D., \& Hamarat, E. (2002). Coping resources, perceived stress, and life satisfaction among Turkish and American university students. International Journal of Stress Management, 9(2), 81-97. https://doi.org/10.1023/A:1014902719664

McClelland, D. C. (1961). Entrepreneurial behavior. In D. C. McClelland, The achieving society (pp. 205-258). https://doi.org/10.1037/14359-006

Mishra, R. K., Sarkar, S., \& Singh, P. (Eds.). (2012). Today’s HR for a Sustainable Tomorrow (Vol.1). Allied Publishers.

Myers, D. G., \& Diener, E. (1995). Who is happy? Psychological Science, 6(1), 10-16. https://doi.org/10.1111/j.1467-9280.1995.tb00298.x

Nagy, Á., \& Székely, L. (2012). The basis and the structure of the tertiary socialisation field and the "Youth-Affairs" as an autonomous area. Acta Technologica Dubnicae, 2(2), 1-18. https://doi.org/10.1515/atd-2015-0055

Örücü E., Kılıç, R., \& Özer, Y. (2007) Üniversite öğrencilerinin girişimcilik eğilimlerinde ailesel faktörlerin etkisi, Girişimcilik ve Kalkinma Dergisi, 2(2), 27-47.

Özdevecioğlu, M., \& Aktaş, A. G. A. (2007). Kariyer bağl1lığı, mesleki bağl1lık ve örgütsel bağlllı̆̆ın yaşam tatmini üzerindeki etkisi: İş-aile çatı̧̧masının rolü. Erciyes Üniversitesi İktisadi ve İdari Bilimler Fakültesi Dergisi, 28, 1-20.

Özgür, G., Babacan G. A., \& Durdu, B. (2010). Evde ve yurtta kalan üniversite öğrencilerinde yaşam doyumu. Psikiyatri Hemşireliği Dergisi, 1(1), 25-32.

Pehlivan, A. E., Kilicsal, L., \& Kizildag, D. (2019). X ve Y kuşaklarının politik davranış algılarının karşılaştırılması. Business and Economics Research Journal, 10(1), 219-232. https://doi.org/10.20409/berj.2019.164

Prensky, M. (2001). Digital natives, digital immigrants. On the Horizon, 9(5). https://doi.org/10.1108/10748120110424816

Robinson, P. B., Stimpson, D. V., Huefner, J. C., \& Hunt, H. K. (1991). An attitude approach to the prediction of entrepreneurship. Entrepreneurship: Theory and Practice, 15, 13-31.

https://doi.org/10.1177/104225879101500405 
Sarıbaş Ö., Kömürcü S., \& Güler M. E. (2016). Yavaş şehirlerde yaşayan Z kuşağının çevre ve sürdürülebilir kalkınma algıları: Seferihisar örneği. Uluslararası Türk Dünyası Turizm Araştırmaları Dergisi, 1(2), 107-119.

Schawbel, D. (2014). Gen Z employees: the 5 attributes you need to know. Retrieved from https://www.entrepreneur.com/article/236560

Schumpeter, J. (1993). Theorie der Wirtschaftlichen Entwicklung: e. Unters. über Unternehmergewinn, Kapital, Kredit, Zins u.d. Konjunkturzyklus (8th ed.). unchanged reprint of the 4th ed. of 1934. 1st ed. 1911, Berlin: Dunker \& Humblot.

Shane, S., \& Venkataraman, S. (2000). The promise of entrepreneurship as a field of research. The Academy of Management Review, 25(1), 217-226. https://doi.org/10.5465/amr.2000.2791611

Shapero, A., \& Sokol, L. (1982). The social dimensions of entrepreneurship. Encyclopedia of Entrepreneurship, $72-90$.

Tari, A. (2011). Z generation. Budapest: Tericum Könyvkiadó.

Tolstykh, T., Gamidullaeva, L., Shmeleva, N., Woźniak, M., \& Vasin, S. (2021). An assessment of regional sustainability via the maturity level of entrepreneurial ecosystems. Journal of Open Innovation: Technology, Market, and Complexity, 7(1), 5. https://doi.org/10.3390/joitmc7010005

Ulama, S. (2016). Turizm lisans öğrencilerinin girişimcilik eğilimleri üzerine bir araştırma: Sakarya Üniversitesi Örneği. International Conference On Eurasian Economies. Session 5D: Turizm, 741-751. https://doi.org/10.36880/C07.01674

Veenhoven, R. (1996b). Happy life-expectancy: a comprehensive measure of quality-of life in nations. Social Indicators Research, 39, 1-58. https://doi.org/10.1007/BF00300831

Yenihan, B. M., Öner, B., \& Balcı, B. (2016). İş doyumu ve yaşam doyumunun demografik özelliklerle ilişkisi: Sakarya'daki AVM'lerin çalışanları üzerine bir araştırma, Siyaset Ekonomi ve Yönetim Araştırmaları Dergisi, $4(1), 33-49$.

Yetim, U. (2003). The impacts of individualism/collectivism, self-esteem, and feeling of mastery on life satisfaction among the Turkish university students and academicians. Social Indicators Research, 61(3), 297-317. https://doi.org/10.1023/A:1021911504113

Yılmaz, B. S., \& Günel, Ö. D. (2011). Üniversite eğitimi ve girişimcilik: bireyleri girişimciliğe yönlendiren etkenler. Akademik Bakış Dergisi, 26, Eylül-Ekim, 1-20.

Yılmaz, E., \& Altınok, V. (2009) Okul yöneticilerinin yalnızlık ve yaşam doyum düzeylerinin incelenmesi, Kuram ve Uygulamada Egitim Yönetimi Dergisi, 15(3), 451-470.

Yüksekbilgili, Z. (2013). Türk tipi Y kuşağı. Elektronik Sosyal Bilimler Dergisi, 12(45), s. 342-353.

\section{Copyrights}

Copyright for this article is retained by the author(s), with first publication rights granted to the journal.

This is an open-access article distributed under the terms and conditions of the Creative Commons Attribution license (http://creativecommons.org/licenses/by/4.0/). 